\title{
Evaluation of generic farming conditions in Eastern Lithuania
}

\author{
Gintaras Jarašiūnas, \\ Irena Kinderienè \\ Lithuanian Research Centre \\ for Agriculture and Forestry, \\ Instituto Av. 1, Akademija \\ LT-58344 Kédainiai Distr., \\ E-mailkaltbs@kaltbs.lzi.lt
}

\begin{abstract}
Agricultural experts' perception and knowledge towards farming conditions and natural agro-environmental problems are important to develop a sustainable rural strategy and may serve when planning land use in sloping agricultural areas to avoid land abandonment. The objective of investigations was to analyze the attitudes of agricultural experts in the Eastern Lithuania region towards the state of the generic agrarian sector, soil erosion processes and natural handicaps. Replies of respondents indicated that the means (the Likert Scale) of the evaluation towards the items "Soil quality", "Agricultural sector development" and "Land suitability for generic agricultural activity" were $2.68,3.11$ and 2.73 , respectively. The evaluations indicating that the mean score perceived by respondents towards impact of soil erosion on common farming activity in the region was 2.63. A questionnaire study showed that respondents recognized that the impact of terrain and soil texture factors on the potential of soil erosion processes is the highest in the region, thus the factor of soil type has been evaluated as the least important. The most frequently noticed topographical parameter of the terrain influencing the intensity of soil erosion was slope steepness (63.1\% of respondents), followed by slope aspect (21.1\%) and length (15.8\%). Hilly terrain and soil acidity constraints by frequency 24.5 and $18.9 \%$, respectively, have showed the most important attitude of respondents, in the content of the natural handicaps limiting successful farming activity in the region. However, the study disclosed that unfavourable climate conditions and soil cover diversity were the two least crucial natural constraints for farming. These empirical findings intended to bring benefits and can help in decision-making framework in order to decide the best soil conservation measures and improving farming conditions in agricultural areas under natural handicaps.
\end{abstract}

Key words: attitude survey, Eastern Lithuania, farming conditions, hilly terrain, natural handicaps, soil erosion

\section{INTRODUCTION}

According to natural agro-environmental conditions and land suitability for agricultural activity Lithuania is divided into three major agro-ecological regions, i. e. East, Middle and West, respectively (Mažvila et al., 2011). The Eastern region is characterized as the most unfavourable for generic agricultural activity relating to natural agro-environmental constraints (handicaps) and, as a result, the agricultural sector is less developed by comparison with the Middle and West regions (Mažvila et al., 2011; Aleknavičius, 2007). In the Eastern Lithuanian region land is mostly used for haying and pasturing, the share of cropped land (areas used for crop) is twice lower than in the Middle Lithuanian region. In the region corresponding to natural qualities with regard to low suitability for the farming share of abandoned land is expanded year in. Moreover, much of the land is cultivated only to receive the EU assistance (Ribokas, Kriaučiunnas, 2012). The predominated farm size is small and according to P. Reidsma et al. (2007) the size of the farm 
in hectares is positively and highly correlated with the economic size of the farm and a larger farm is a priori expected to have more capital available for investments. Moreover, household's welfare depends on the size of a farm (Welch, 2009). The quality of the land or a lack of agricultural investment is a significant limiting factor (Gamborg et al., 2012). The biggest area of abandoned land is fixed in Eastern Lithuania where infertile soils prevail and the number of working rural inhabitants is smaller compared with the Middle and West regions (Aleknavičius, 2007). The amount of Less Favoured Areas (LFA's) was $76.57 \%$ on all agricultural land of Eastern Lithuania. On the average, in Lithuania farmers and agricultural enterprises use $81.4 \%$ of agricultural land, thus in the Eastern Lithuania region only $58.2 \%$, respectively (Results of..., 2012). Furthermore, agricultural development is active in the regions with high quality soils, whereas in regions with non-productive soils the development is relatively slower (Aleknavičius, Stravinskiene, 2011).

About 52\% of Lithuania's relief consists of undulating hills, where the soil is erodible (Kudaba, 1983). About $17 \%$ of Lithuania's agricultural land is eroded, increasing to $43-58 \%$ in hilly regions (Jankauskas, 1996; Jankauskas, Fullen, 2002). Erosion processes affect the majority of the overall rolling terrain of Lithuania by over $20-30 \%$ and by more than $30 \%$. The highest rate of soil erosion occurs in Eastern Lithuania (Česnulevičius, 2013) involving land degradation and risk of land abandonment. Investigations of water erosion on $5-7^{\circ}$ slopes of the Baltic uplands (Eastern Lithuania) show that runoff and losses of clay loam soil due to water erosion range markedly: from $6.6 \mathrm{~mm}$ of runoff water under wasteland to $151 \mathrm{~mm}$ under bare fallow, or from $4.5 \mathrm{Mg} \mathrm{ha}^{-1} \mathrm{yr}^{-1}$ of soil under cereal crops to $46.6 \mathrm{Mg} \mathrm{ha}^{-1} \mathrm{yr}^{-1}$ on bare fallow (Bundinienè, Paukšte, 2002). The area under a very moderate hilly terrain has accounted $80 \%$ of the Baltic uplands territory (Kudaba, 1983).

Several different factors have an impact on erosion risk including climate, type of soil, topography, erosion prevention methods and crop types (Morgan, 2006). The influence of topography on erosion is of great importance (Aksoy, Kavvas, 2005). In the global context, climate and the soil are the most important factors determining the extent and severity of soil degradation by soil erosion (Lal, 1998; Korytny et al., 2003).

The means of land productivity in the East, West and Middle Lithuanian regions are 36.33, 37.61 and 46.61 points, respectively. In the studied region, Albeluvisol and Luvisol soils prevail. Natural handicaps, related to climate, soil and terrain criteria (Van Orshoven et al., 2012), are predominated in the agro-ecological Eastern Lithuania region compared with the Middle and West regions, respectively. Therefore, low temperature criterion (length of growing period defined by number of days with daily average temperature $>5^{\circ} \mathrm{C}$ ), as the main indicator of unfavourable climate conditions, consists of $20.93 \%$ of the region area, thus $51.96 \%$ less than in the West and 59\% more than in the Middle regions. Land under low temperature that is systematically not sufficient for crops to complete the production cycle is unfavourable for agriculture (Eliasson et al., 2010). The percentage of agricultural land under unfavourable soil texture (relative abundance of clay, silt, sand, organic matter and coarse material fractions in topsoil material) consists of $48.88 \%$ on all agricultural land in the region, thus in the West and Middle regions this criterion takes part of $38.10 \%$ and $21.33 \%$, respectively. Texture affects workability (ease of tillage), water infiltration, runoff and water movement within the soil (Eliasson et al., 2010). Poorly drained soils (most associated with Gleysols and Planasols) amount to $7.35 \%$ on all agricultural land of the region. Agricultural land under steep slopes $\left(>15 \% / 7^{\circ}\right)$ in Eastern Lithuania consists of $2.18 \%$, these amounts in the West and Middle regions are $0.61 \%$ and $0.47 \%$, respectively. Slope remains the sole topographic criterion for its decisive impact on farming opportunities (Van Orshoven et al., 2012). Slope steepness is the central parameter of agricultural terrain classification to its suitability for general agricultural activity in Lithuania (Lietuvos dirvožemiai, 2001). In summary, the agricultural land of the Eastern Lithuania region is attributed to low suitability for generic agricultural activity by natural conditions and is associated with non-productive land, hilly terrain and high risk for soil degradation.

The aim of this study is to investigate attitudes of the agricultural experts in the Eastern Lithuania region towards the generic agrarian sector, soil 
erosion and natural constraints of farming activity and conditions.

\section{MATERIALS AND METHODS}

Study area. In this study a selected Eastern Lithuania agro-ecological region was analyzed (Fig. 1) which consists of 22 rural municipalities. From the geographical point of view, Lithuania has four main relief units in its territory: lowlands, plains, plateaus and hills (Česnulevičius, 2010). The majority of municipalities of the Eastern region fall under Baltic uplands, where the hilly terrain with steep slopes is the dominant topographical character. In the hills of Baltic uplands the highest point of the Lithuanian terrain is located. In general, the altitudes are over $200 \mathrm{~m}$ above the sea level. The highest point of terrain in Lithuania is $293.84 \mathrm{~m}$ a. s. l., named Aukštojas Hill and located in the Medininkai uplands (southeastern part of Eastern Lithuania). Conditions for water and tillage erosion in Lithuania are the most favourable on the hilly terrain (Lietuvos dirvožemiai, 2001). Every year such areas are deprived of 20-100 tha ${ }^{-1}$ of the smallest soil particles and a high amount of nutrients (Vaičys, Mažvila, 2009). The variety of relief gives a great diversity to its generic agricultural activity characteristics and certain specificity in hilly agricultural areas. The dominant climate has the continental character (Rimkus et al., 2007), with the mean annual precipitation varying between 600 to $800 \mathrm{~mm}$ (Meteorologinis biuletenis, 2014).
Attitudes survey. The agricultural region of Eastern Lithuania was selected as the territorial entity of the survey with reference to J. Mažvila et al. (2011). The study was cross-sectional and the data were collected at a single period of time (March and April 2014). The statistical population that was assessed in this study consisted of 64 agricultural experts who were official employees in Lithuanian rural municipalities. Twenty-one questionnaires were distributed with proportional allocation by the stratified random sampling method (different municipalities were considered as the class). The data were collected through a questionnaire mailed out to the agricultural experts. A total of nineteen $(\mathrm{n}=19)$ agricultural experts returned questionnaires with the survey response rate of $90 \%$. No questionnaires were eliminated owing to incorrect filling. The questionnaire was comprised of three parts based on experts' opinion about the generic agricultural status and conditions in the Eastern Lithuania region. The five (from 1 to 5 ) and six (from 0 to 6) point Likert Scale was used (Likert, 1932). The questionnaire included three parts. The first part included 3 items related to "Soil quality" (5-point Likert Scale ranged from 1 = very low quality to $5=$ very high quality), "Agricultural sector development" ( $1=$ very low development to $5=$ very high development) and "Land suitability for generic agricultural activity" ( $1=$ very low suitability to 5 = very high suitability); the second part of the study covered the perceived factors (i. e. soil

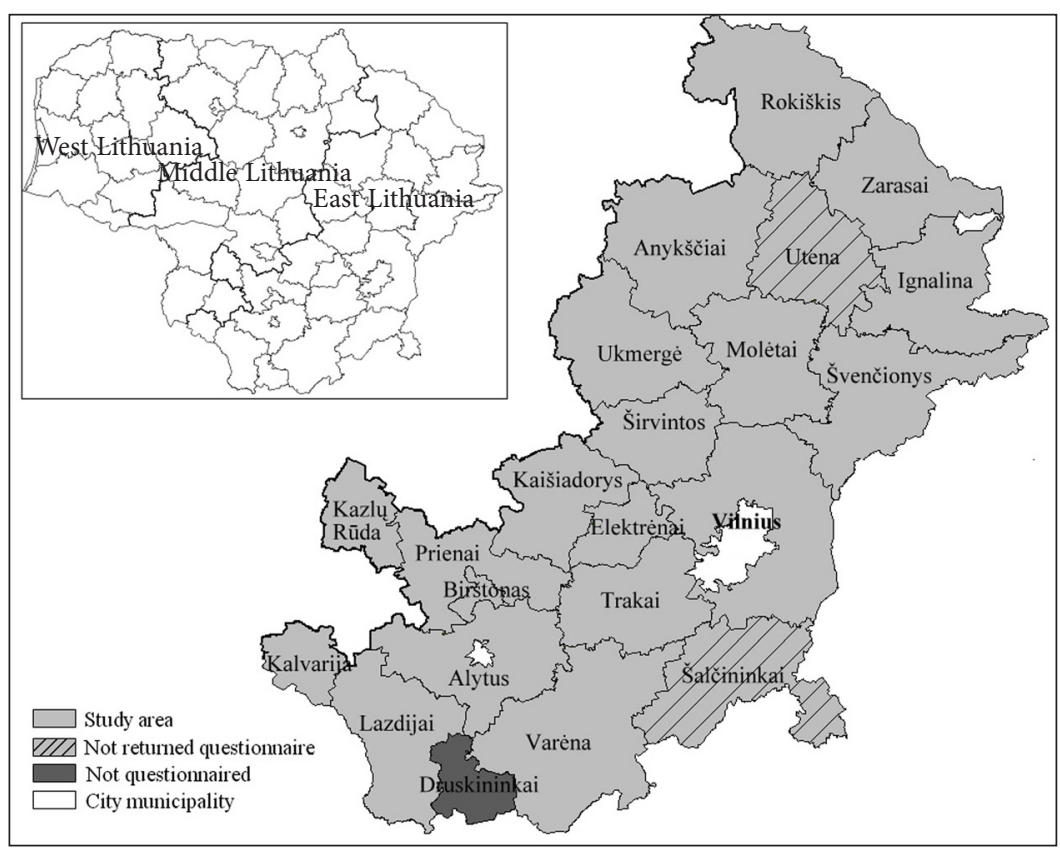

Fig. 1. Location map of the study area 
type, soil texture, vegetation, terrain and climate) influencing the potential of soil erosion, and this part also included the attitudes towards topographical terrain parameters (i. e. slope steepness, aspect and length) influencing the intensity of soil erosion; the third part included 8 items for the assessment of the attitudes of agricultural experts towards natural constraints negatively affecting generic farming activity. Additionally, according to the official requirement the person (employee) working at the Agricultural Office must have higher education in agricultural science.

Data analysis. Appropriate descriptive statistics such as means, standard deviations, variation coefficients, frequencies and non-parametric Spearman's rank correlations with a significance level of $p \leq 0.05$ were used to analyze the data (Gaur, 2007; Cohen et al., 2003). Questionnaire reliability was estimated by calculating Cronbach's alpha (Hogg, 2006), which was 0.78. Data were analyzed using the Statistical Package for the Social Sciences (SPSS 11.5) software by the methodology of Bryman and Cramer (1997). The map has been produced in the ArcMap 10 software.

\section{RESULTS}

Estimation of the agricultural sector. The mean of the respondents on their attitude towards the item "Soil quality" was estimated 2.68 (Table 1). The majority of experts (57.9\%) in the questionnaire have stated that the quality of prevailing soils is "moderate" (3 scores). However, 31.6 and $10.5 \%$ of experts stated that the soil quality is "low" (2 scores) and "high" (4 score), respectively. Neither of the scores at the extremes (1 and 5) was used in the "Soil quality" evaluation by the respondents. The findings showed that the mean evaluation of the "Agricultural sector development" item was 3.11. The mean of the perceived item "Agricultural sector development" was higher than on the attitudes towards the items "Soil qual- ity" and "Land suitability for generic agricultural activity" with values of 0.43 and 0.38 , respectively. The results showed that most experts (57.9\%) stated that the item "Agricultural sector development" was "moderate" (3 scores). Only three responses $(15.8 \%)$ showed that the item "Agricultural sector development" was "low", and five (26.3\%) experts noted it as "high". Regarding the perception on the item "Soil quality", no experts gave scores of 1 or 5. The mean of the perceived item "Land suitability for generic agricultural activity" was 2.73. However, $62.8 \%$ of experts among the total number of the respondents scored "Land suitability for generic agricultural activity" with a value of 3. According to the agricultural experts' attitudes it might be concluded that the item "Agricultural sector development" was estimated better than the items "Soil quality" and "Land suitability for generic agricultural activity".

Based on the results of the agricultural experts' survey it was revealed that the correlation between experts' perceived scores of the items "Soil quality" and "Agricultural sector development" was low and non-significant ( $p>0.05, r=0.33, n=19)$. Therefore it can be stated that experts who estimated the item "Soil quality" better (higher scores) also estimated the item "Agricultural sector development" more positively (higher scores). The analysis proved that there existed a significant correlation between experts' perceived scores of the items "Soil quality" and "Land suitability for generic agricultural activity" ( $p \leq 0.05, r=0.67$, $n=19$ ). It can be stated that the quality of soil is related to land-use decisions and land utilization possibilities. Experts' perceived scores of the items "Agricultural sector development" and "Land suitability for generic agricultural activity" were non-significant, thus positive relationship $(p>0.05, r=0.36, n=19)$.

The importance of land productivity on agricultural sector development has a dominant character. Lower land productivity associated negative impacts

Table 1. Attitudes of the agricultural experts towards the items related to generic agrarian sector

\begin{tabular}{|c|c|c|c|c|}
\hline Items & $n$ & Mean* $^{*}$ & Standard deviation & $\begin{array}{c}\text { Variation coefficient, } \\
\%\end{array}$ \\
\hline Soil quality & \multirow{3}{*}{19} & 2.68 & 0.58 & 20.70 \\
\hline Agricultural sector development & & 3.11 & 0.66 & 21.18 \\
\hline Land suitability for generic agricultural activity & & 2.73 & 0.52 & 20.16 \\
\hline
\end{tabular}

* Mean according to the Likert Scale (1-5 spectrums). 
include decline in crop yield, limit crop choice and farming income, encourage land abandonment risk. Hazards, even such as socioeconomic determinants, depend on land productivity. The survey results showed that non-significant correlation coefficient was achieved between land productivity (points) and experts' perceived scores of the item "Soil quality" ( $p>0.05, r=0.42, n=19)$. However, land productivity significantly correlated with agricultural experts' perceived scores of the items "Agricultural sector development" ( $p \leq 0.05, r=0.53, n=19$ ) and "Land suitability for generic agricultural activity" ( $p \leq 0.05, r=0.78, n=19$ ). The results showed that the land productivity variable was an important determinant of the perceived items "Land suitability for generic agricultural activity" and "Agricultural sector development" regarding experts' perception.

Natural factors of soil erosion. In general, according to the evaluations made in the Likert Scale, the survey indicating that the value of the mean score perceived by the respondents towards the impact of soil erosion on generic agricultural activity in the region was 2.63 . The majority $(52.7 \%)$ of the respondents perceived that the impact of soil erosion on farming is "moderate" (3 scores), thus $26.3 \%$ of the respondents were of the opinion that this impact was "weak" ( 2 scores) and $10.5 \%$ estimated it as "very weak" (1 score) and "high" (4 scores), respectively. No one respondent has noticed "no impact" (0 score) and "very high impact" (5 scores), respectively.

The Likert Scale measurement highlighted the highest importance of the terrain factor on the potential of soil erosion processes by the respondents (Fig. 2). The respondents stated that soil texture

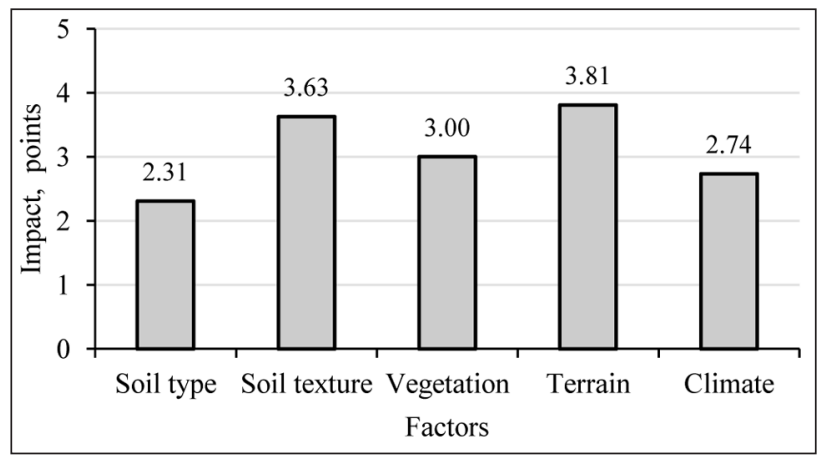

Fig. 2. The impact of natural factors on the potential of soil erosion in Eastern Lithuania evaluated by the respondents was also considered to be an important factor on soil erosion.

The respondents evaluated the vegetation factor to have a moderate impact on soil erosion in Eastern Lithuania. The respondents estimated that their attitudes towards the impact of the climate factor were higher than that of the soil type, respectively. Based on the survey results, the soil type has been evaluated as the least important factor causing soil erosion processes in Eastern Lithuania. This study showed that agricultural experts of the Eastern Lithuania region recognized that the impact of terrain and soil texture factors on soil erosion processes is the highest. This indicates that the respondents have in general adequate understanding and knowledge about the soil erosion problem, its origin and features in the Eastern Lithuania region. This study clearly flagged out the factors that significantly determine the processes of soil erosion in the Eastern Lithuania region. This knowledge is important to develop a sustainable rural strategy and in order to promote improving soil and natural environment quality in the region.

Terrain is often seen as a natural constraint that plays the most part on the land degradation and involves rapidly growing deagrarisation in the Eastern Lithuania region. There were notable differences in the evaluations concerning the impact of topographical terrain parameters on the intensity of soil erosion (Fig. 3). It was noticed that $63.1 \%$ of the respondents considered slope steepness as the main terrain parameter influencing the intensity of soil erosion in Eastern Lithuania. However, the results show that 21.1 and $15.8 \%$ of them assumed that the slope aspect and slope length were the main terrain parameters as a major cause for processes of soil erosion in the region.

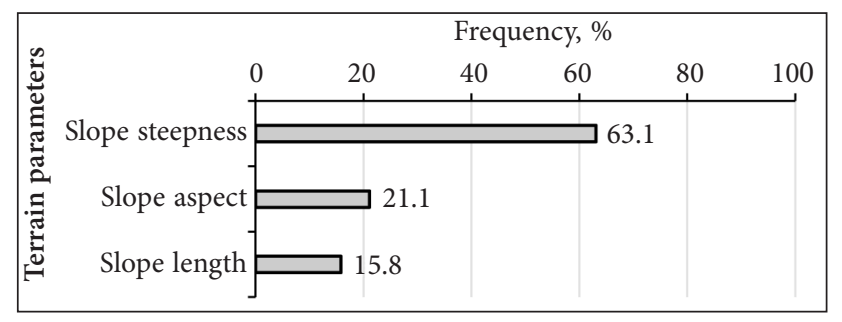

Fig. 3. Topographical terrain parameters mostly influencing the intensity of soil erosion in Eastern Lithuania evaluated by the respondents' 
Natural constraints of the region. Based on the results of the questionnaire survey, this study assessed the negative natural causes of farming activity in the region. The study of frequency of the replies given on the attitude of agricultural experts on the mentioned eight natural constraints showed that the hilly terrain had the highest frequency (24.5\%) followed by soil acidity (18.9\%), then, unfavourable soil agro-chemical (17\%) and agro-physical (13.2\%) properties, respectively (Fig. 4).

According to the opinion of respondents, the constraint of the hilly terrain closely associates with the problem of higher risk for soil erosion, both by wind and by water, therefore it becomes more difficult to manage the land (mechanization is hampered and may require specific equipment, access to land and all agricultural operations become more time-consuming), and soil degradation and abandoned agricultural land problems can be identified. This suggests that the topography has a marked impact on soil physico-chemical properties and affects workability (ease of tillage) in agricultural areas characterised by the hilly terrain. Perceived soil acidity constraint is associated with both the required liming and soil fertility loss. Among eight constraints on the theme of natural handicaps, the perceptions of the respondents on four constraints, i. e. unfavourable climate conditions, soil erosion, limited (poorly) soil drainage and soil cover diversity, showed they had low attitude. For the experts of the Eastern Lithuania region, unfavourable climate conditions and soil cover diversity were the two least important constraints from natural handicaps negatively influencing farming activity.

\section{DISCUSSION}

Experts' knowledge and perception towards the overall view and interpretation against the agrarian sector, soil erosion and natural constraints are grounded on personal experiences and observations. The findings from this study revealed variations in the attitudes towards the local agrarian sector status and perceptions on the soil erosion problem and natural constraints among the experts belonging to the same territorial entity. The Eastern Lithuanian agro-ecological region is not so important in Lithuania for agricultural development due to quite unfavourable agro-ecological conditions, especially in consequence of the hilly terrain and soil acidity. In the present research the respondents have stated that soil quality is lower than moderate, and according to J. Mažvila et al. (2011) soils here provide very unsuitable conditions for cultivation of all arable crops, fruit and vegetables. Many authors (Bieliauskas, 1986; Jankauskas, Jankauskiene 2003; Kinderienè, 2006) have proposed and suggest different anti-erosive systems (crop rotations) to protect soil from degradation processes (erosion, nutrients leaching, surface runoff) and to improve soil quality in the Lithuanian agricultural land situated in hilly areas. Even so, in these regions alternative activities, i. e. afforestation, crafts and rural tourism development, should play the main role for rural development. This region offers very favourable conditions for the dairy and cattle sector. The results revealed that according to respondents' opinion, the quality of soil was estimated lower than moderate and it reflects that understanding and knowledge of the impact of natural and environmental

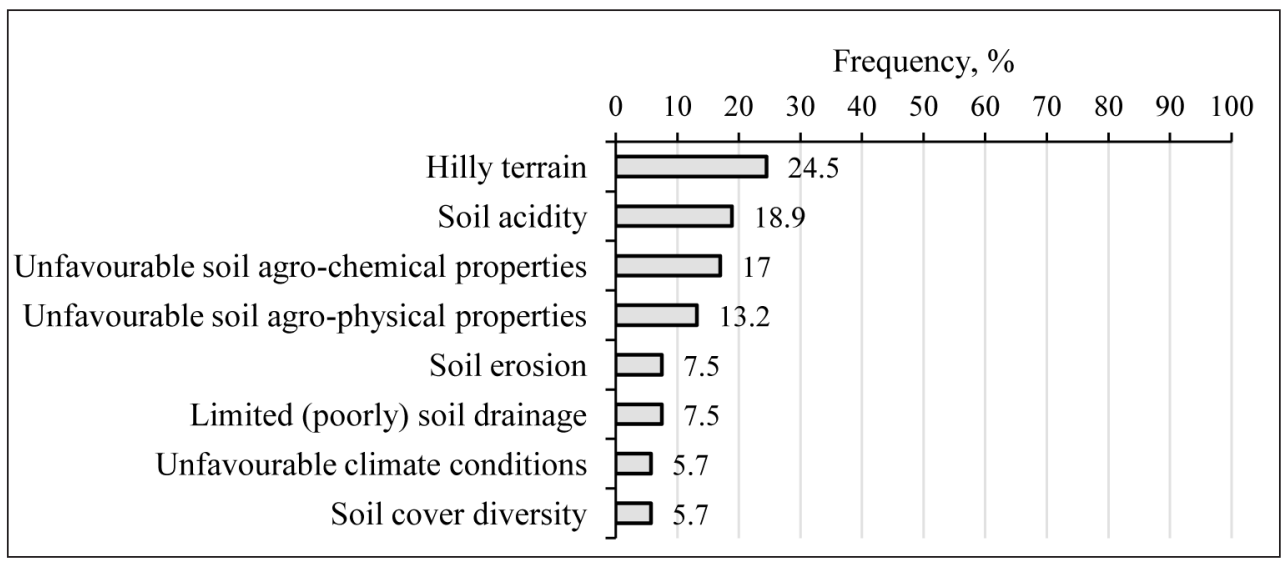

Fig. 4. Frequency distribution of natural constraints in Eastern Lithuania perceived by the respondents 
constraints on the agrarian sector have adequate approach. J. Milius and G. Ribokas (2008) have noticed that in Lithuanian's hilly areas mostly due to unfavourable natural constraints agricultural activity brings little profit and in a number of cases is detrimental.

Agricultural land suitability for farming activities is mostly determined by soil properties and topographical features. Agricultural development in Eastern Lithuania is limited due to low soil fertility and hilly undulating terrain (Švarcaitè, 2003), and this statement agrees with the conducted general conclusions from experts' survey. Soils on the sloping land are eroded and not suitable for successful growing of crops by the reason of steep slopes relating to intensive water and tillage erosion, which causes potential reduction of yield, important fertile topsoil is lost from agricultural land and leads to land degradation processes (Kinderienè et al., 2013). In Eastern Lithuania, soils are glacio-fluvial Arenosols and Luvisols (Soil Atlas of Europe, 2005). They have a low status of available phosphorus $\left(\mathrm{P}_{2} \mathrm{O}_{5}\right)$ and potassium $\left(\mathrm{K}_{2} \mathrm{O}\right)$. In the south-eastern part of the region the most common type of soils is Arenosol, as soil type they have very low resistance to wind erosion, the soils are acidic (Vaičys, Mažvila, 2009). In some Eastern Lithuanian administrative districts, acid soils covered 70-93\% (Eidukevičiene et al., 2010). The survey has indicated the acid soils problem that needs solving and that mitigating measures should be used rapidly. Conditions for water erosion in Lithuania are the most favourable on the hilly terrain. As stated by B. Jankauskas (2012), the most vulnerable to water erosion are terrains having light soil texture on steep slopes.

The findings from this study suggest that the main factors determining soil erosion rate on agricultural land are terrain, soil lithology and cover plant, thus supporting findings of other studies, such as Ž. Denas et al. (2006) and B. Jankauskas (2012). In Lithuania topography and vegetation have a great influence on soil erodibility. Moreover, the terrain is often seen as a natural constraint that plays the most part on land degradation and involves rapidly growing deagrarisation in the Eastern Lithuania region. High rainfall rates in steeply sloped areas with poor vegetation and absence of protective measures will result in high rates of soil erosion (Morgan, 1996). The survey results presented here tend to agree with the above-mentioned authors.

Generally, the soils in the region have a low status of humus (from 1.6 to $2.2 \%$ ), especially eroded soils. Erosion leads to the decrease of soil quality. Agricultural land on a wide range of soil cover diversity is mainly found in the areas with hilly terrain with often strongly varying and relatively poor conditions for agricultural use. Chemical and physical properties of soils are factors influencing land-use decisions, agricultural development, farming systems use and land utilization possibilities. Consequently, to combat deagrarization process in the Eastern Lithuania region a successful rural development policy and soil conservation programmes are an urgent need.

The results of the empirical survey provided the present agrarian sector status, problem of soil erosion and indicators of apparent situation of natural constraints in Eastern Lithuania. Personal experience and perception provide additional inputs into the complexity of generic agrarian sector and natural hazards knowledge of the Eastern Lithuania region. Hence, the survey method can be successfully conducted on purpose to identify the most pressing agrarian problems in a relatively short time. An empirical survey that measured attitudes towards the generic agricultural status and problems can be very useful to farmers, land managers and for planning rural development programmes. The results obtained in the survey may serve when planning land use in sloping agricultural areas to avoid land abandonment and for the purpose of developing the agricultural sector especially in natural handicapped areas.

\section{CONCLUSIONS}

The survey results indicated that the mean perceived attitudes of agricultural experts towards the items "Soil quality", "Agricultural sector development" and "Land suitability for generic agricultural activity" in the Eastern Lithuania region were $2.68,3.11$ and 2.73 , respectively. The evaluations indicating that the value of mean score perceived by the respondents towards the impact of soil erosion processes on generic agricultural activity was 2.63 . This study showed that the respondents recognized that the impact of terrain and soil texture factors on the potential of soil 
erosion processes is the highest in the region, thus the factor of soil type has been evaluated as the least important.

It was noticed that $63.1 \%$ of the respondents considered slope steepness as the main topographical terrain parameter markedly influencing the intensity of soil erosion in Eastern Lithuania. The most important natural constraints negatively influencing generic farming activity noticed by the surveyed experts are the hilly terrain, soil acidity and unfavourable soil chemical and physical properties. For the experts of Eastern Lithuania, unfavourable climate conditions and soil cover diversity were the two least important constraints.

These findings intended to bring benefits and can help in decision-making framework in order to decide the best soil conservation measures, by planning rural development programmes and improving farming conditions in agricultural areas under natural handicaps. This knowledge is important to develop a sustainable rural strategy and in order to promote improving soil, natural environmental quality and farming possibilities in the region.

\section{ACKNOWLEDGEMENTS}

We would like to express our sincere thanks to agricultural experts from the Agricultural Office in Eastern Lithuania rural municipalities that participated in the survey.

Received 18 March 2015 Accepted 17 June 2015

\section{REFERENCES}

1. Aksoy H., Kavvas M. L. 2005. A review of hillslope and watershed scale erosion and sediment transport models. Catena. Vol. 64. P. 247-271.

2. Aleknavičius P. 2007. Kaimiškųjų teritorijų žemès naudojimo problemos. Žemés ūkio mokslai. Vol. 14(1). P. 82-90.

3. Aleknavičius P., Stravinskienè V. 2011. Žemès savybių ittaka žemès ūkio plètrai Lietuvoje. Kaimo raidos kryptys žiniu visuomenèje. Vol. 2. P. 188198.

4. Bieliauskas P. 1986. Dirvosauginė žemdirbystè kalvose. Vilnius. $88 \mathrm{p}$.

5. Bryman A. E., Cramer D. 1997. Quantitative Data Analysis with SPSS for Windows: A Guide for Social Scientists. Routledge.
6. Bundinienė O., Paukštė V. 2002. Lietuvos žemdirbystès instituto Dūkšto bandymų stoties veikla 1960-2000. Žemés ūkio mokslai. Vol. 4. P. 45-53.

7. Cohen J., Cohen P., West S. G., Aiken L. S. 2003. Applied Multiple Regression/Correlation Analysis for the Behavioral Sciences. 2nd ed. Hillsdale, NJ: Lawrence Erlbaum Associates.

8. Česnulevičius A. 2010. Geomorfologija. Vilnius: LEU leidykla. $356 \mathrm{p}$.

9. Česnulevičius A. 2013. Reljefas. Iš: Lietuvos gamtine geografija. Klaipeda: Klaipedos universiteto leidykla. P. 30-52.

10. Denas Ž., Kumetaitis A., Šliaupa S., Zakarevičius A., Šliaupienè R. 2006. Lietuvos žemès paviršiaus erozijos modeliavimas ir kartografavimas taikant GIS technologijas. Geodezija ir kartografija. Vol. 32(3). P. 57-61.

11. Eidukevičienè M., Volungevičius J., Marcinkonis S., Tripolskaja L., Karčauskienè D., Fullen M. A., Booth C. A. 2010. Interdisciplinary analysis of soil acidification hazard and its legacy effects in Lithuania. Natural Hazards and Earth System Sciences. Vol. 10. P. 1477-1485.

12. Eliasson A., Jones R. J. A., Nachtergaele F., Rossiter D. G., Terres J. M., Van Orshoven J., Van Velthuizen H., Bottcher K., Haastrup P., Le Bas C. 2010. Common criteria for the redefinition of intermediate less favoured areas in the European Union. Environmental Science \& Policy. Vol. 13. P. 766-777.

13. Gamborg C., Millar K., Shortall O., Sandøe P. 2012. Bioenergy and land use: framing the ethical debate. Journal of Agricultural \& Environmental Ethics. Vol. 25. P. 909-925.

14. Gaur A. S. 2007. Statistical Methods for Practice and Research: A Guide to Data Analysis Using SPSS. New Delhi: Response Books.

15. Hogg R. 2006. Probability and Statistical Inference. 7 th ed. Pearson.

16. Jankauskas B., Fullen M. A. 2002. A pedological investigation of soil erosion severity on undulating land in Lithuania. Canadian Journal of Soil Science. Vol. 82. P. 311-321.

17. Jankauskas B., Jankauskiene G. 2003. Erosionpreventive crop rotations for landscape ecological stability in upland regions of Lithuania. Agriculture, Ecosystems and Environment. Vol. 95. P. $129-142$.

18. Jankauskas B. 1996. Dirvožemio erozija. Vilnius: Margi raštai. $167 \mathrm{p}$.

19. Jankauskas B. 2012. Soil erosion: case study of Lithuania. In: Sustainable Agriculture. Ecosystem Health and Sustainable Agriculture. Uppsala: Baltic University Press. P. 231-238.

20. Kinderienè I., Jarašiūnas G., Karčauskienè D. 2013. Augalų maisto medžiagų (N, P, K) nuo kalvų šlaitų praradimas su dirvožemiu ir vandeniu. Žemès ūkio mokslai. Vol. 20(1). P. 10-19. 
21. Kinderienè I. 2006. Supaprastinto žemès dirbimo bei augalų masès itterpimo naudojimo ittaka dirvožemio vandeninei erozijai. Žemès ùkio mokslai. Vol. 2. P. 1-7.

22. Korytny L. M., Bazhenova O. I., Martianova G. N., Ilyicheva E. A. 2003. The influence of climatic change and human activity on erosion processes in sub-arid watersheds in southern East Siberia. Hydrological Processes. Vol. 17. P. 3181-3193.

23. Kudaba Č. 1983. Lietuvos aukštumos. Vilnius: Mokslas. 186 p.

24. Lietuvos dirvožemiai. 2001. Eidukevičienè M., Vasiliauskienė V. (red.). Vilnius: Lietuvos mokslas. Kn. 32.1244 p.

25. Lal R. 1998. Soil erosion impact on agronomic productivity and environment quality. Critical Reviews in Plant Sciences. Vol. 17(4). P. 319-464.

26. Likert R. 1932. A technique for the measurement of attitudes. Archives of Psychology. Vol. 140. P. 1-50.

27. Mažvila J., Staugaitis G., Vaišvila Z., Aleknavičius P., Juozokas A., Mockevičius R., Lukšienė L. 2011. Lietuvos žemès našumas: monografija. Akademija, Kèdainių r. 280 p.

28. Meteorologinis biuletenis. 2014. Vilnius: Lietuvos hidrometeorologijos tarnyba.

29. Milius J., Ribokas G. 2008. Dirvonai Lietuvos XX ir XXI amžių laukuose. Geografija. Vol. 44(1). P. 9-16.

30. Morgan R. P. C. 1996. SoilErosion and Conservation. 2nd ed. Harlow: Longman. 198 p.

31. Morgan R. P. C. 2006. Soil Erosion and Conservation. 3rd ed. Oxford, England: Blackvell Publishing. 304 p.

32. Reidsma P., Ewert F., Lansink A. O. 2007. Analysis of farm performance in Europe under different climatic and management conditions to improve understanding of adaptive capacity. Climatic Change. Vol. 84(3-4). P. 403-422.

33. Results of the Agricultural Census of the Republic of Lithuania 2010 by Ward. 2012. Vilnius: Statistics Lithuania. 168 p.

34. Ribokas G., Kriaučiūnas E. 2012. Rytų Lietuvos žemėnaudos pokyčiai Vilniaus miesto ittakos kontekste. Ekonomika ir vadyba: aktualijos ir perspektyvos. Vol. 3(27). P. 156-163.

35. Rimkus E., Kažys J., Junevičiūtė J., Stonevičius E. 2007. Lietuvos klimato kaitos prognozavimas XXI amžiuje. Geografija. Vol. 2(43). P. 56-64.

36. Soil Atlas of Europe. 2005. European Soil Bureau Network, European Commission. Luxembourg: Office for Official Publications of the European Communities.
37. Švarcaitė I. 2003. Antierozinių priemonių sistema Baltijos kalvyno aukštumose. Geografija. Vol. 39(2). P. 52-62.

38. Vaičys M., Mažvila J. 2009. The influence of soil characteristics on plant productivity and ecological stability. Ekologija. Vol. 55(2). P. 99-106.

39. Van Orshoven J., Terres J. M., Tóth T. 2012. Updated Common Bio-physical Criteria to Define Natural Constraints for Agriculture in Europe. Luxemburg: European Commission, EUR 25203 EN.

40. Welsh R. 2009. Farm and market structure, industrial regulation and rural community welfare: conceptual and methodological issues. Agriculture and Human Values. Vol. 26(1-2). P. 21-28.

\section{Gintaras Jarašiūnas, Irena Kinderienè \\ ŪKININKAVIMO SĄLYGŲ IVERTINIMAS RYTŲ LIETUVOJE}

\section{Santrauka}

Tyrimo tikslas - nustatyti ir ịvertinti žemès ūkio specialistų, dirbančių Rytų Lietuvos regione, požiūrị i bendrąją žemès ūkio situaciją, dirvožemio eroziją ir natūralias gamtines kliūtis, ribojančias žemès ūkio veiklą. Aiškinantis specialistų $(n=19)$ nuostatas, buvo naudojamas uždaro ir atviro tipo klausimynas. Tyrimas atliktas $2014 \mathrm{~m}$. kovo-balandžio mèn. Respondentų nuomone (pagal 5 balų Likert skalę), dirvožemio kokybè, žemès ūkio sektoriaus išvystymas ir žemès ūkio paskirties žemès tinkamumas plètoti ūkinę veiklą buvo ịvertinti atitinkamai: vidutiniškai 2,68; 3,11 ir 2,73 balais. Nustatyta, kad specialistai dirvožemio erozijos procesų ịtaką ūkininkavimui regione ịvertino vidutiniškai 2,63 balų. Nustatyta, kad pagrindiniai natūralūs gamtiniai veiksniai, lemiantys dirvožemio erozijos potencialą regione, yra reljefas bei dirvožemio granuliometrinè sudètis, o dirvožemio grupès veiksnys buvo įvertintas kaip turintis mažiausią i taką erozijai. Daugumos respondentų nuomone $(63,1 \%)$, pagrindinis reljefo parametras, lemiantis erozijos intensyvumą regione, yra šlaito statumas. Tyrimas parodè, kad pagrindinès natūralios gamtinès kliūtys, ribojančios ūkininkavimą regione, respondentų nuomone, yra kalvotas reljefas $(24,5 \%$ respondentų) ir dirvožemio rūgštumas $(18,9 \%)$. Nepalankios klimato sąlygos ir dirvožemio dangos margumas, respondentų vertinimu, yra mažiausiai reikšmingos natūralios gamtinès kliūtys, ribojančios žemės ūkio veiklą regione.

Raktažodžiai: požiūrio ịvertinimas, Rytų Lietuva, ūkininkavimo sąlygos, kalvotas reljefas, natūralios gamtinès kliūtys, dirvožemio erozija 